\title{
Implementasi Sistem Pakar dengan Algortima Naïve Bayes dengan Laplace Correction untuk Diagnosis Tuberkulosis Paru
}

\author{
Yanti Apriyani ${ }^{1}$, Iqbal Dzulfiqar Iskandar ${ }^{2}$, Mira Kusmira ${ }^{3}$, Melisa Winda \\ Pertiwi $^{4}$, Imam Amirulloh ${ }^{5}$, Taufik Wibisono ${ }^{6}$ \\ ${ }^{1,2,5,6}$ Program Studi Sistem Informasi, Teknik dan Informatika \\ ${ }^{1,2,5,6}$ Universitas Binasarana Informatika \\ ${ }^{3,4}$ Program Studi Sistem Informasi \\ ${ }^{3,4}$ Sekolah Tinggi Manajemen Informatika dan Komputer Nusa Mandiri \\ Email : yanti.ynp@bsi.ac.id ${ }^{1}$, Iqbal.iql@bsi.ac.id ${ }^{2}$, mira.mik@bsi.ac.id ${ }^{3}$, \\ melisa.mwp@bsi.ac.id ${ }^{4}$,Imam.iau@bsi.ac.id ${ }^{5}$, taufik.tik@bsi.ac.id ${ }^{6}$
}

\begin{abstract}
ABSTRAK
Tuberkulosis atau tuberculosis (TBC) merupakan salah satu penyakit menular berbahaya yang disebabkan oleh kuman dari kelompok Mycobacterium Tuberculosis. Sebagian besar kuman tuberkulosis menyerang organ paru-paru dan menyerang organ yang lainnya. Menurut WHO Indonesia menjadi salah satu negara dengan beban tuberkulosis tinggi dengan jumlah kasus terbaru Tuberkulosis di Indonesia mencapai 420.994 kasus pada tahun 2017, hal tersebut dipengaruhi oleh kurangnya pengetahuan masyarakat akan tuberculosis dan enggan untuk memeriksakan gejala-gejala awal yang diderita kepada dokter.

Dari permasalahan tersebut perlu dibangun sebuah sistem pakar yang berbasis perangkat lunak bertujuan untuk membantu dan memudahkan masyarakat dalam mendiagnosis gejala awal tuberculosis sebelum berkonsultasi kepada tenaga Kesehatan lebih lanjut. Diagnosis penyakit dengan menggunakan sistem pakar memerlukan sebuah metode algoritma dalam penyelesaiannya. Pada riset ini metode yang digunakan untuk membangun perangkat lunak sistem pakar diagnosis tuberculosis paru menggunakan waterfall, sedangakan proses klasifikasi untuk menentukan Diagnosis menggunakan algortima Naïve Bayes dengan Laplace Correction. Tujuan dari riset ini adalah untuk mendiagnosis gejala-gejala yang dialami pasien dan dapat menyimpulkan layaknya seorang pakar atau dokter saat mendiagnosis pasiennya serta memberikan pengetahuan gangguan apa yang diderita oleh pasien.

Terkait hasil riset ini adalah berupa aplikasi sistem pakar Diagnosis penyakit $t u$ berculosis paru berbasis desktop, dan telah dilakukan Pengujian sistem. Pengujian sistem ini dilakukan menggunakan black box testing yang berfokus pada proses masukan dan keluaran dari aplikasi terhadap perangkat lunak Diagnosis penyakit tuberkulosis. Sedangkan data hasil uji aplikasi Diagnosis menunjukan Kelas Positif Tuberkulosis lebih besar dengan nilai 0.000129803, dibandingkan dengan nilai kelas Negatif Tuberkulosis dengan nilai 0.0000000018. Maka dapat dinyatakan bahwa pasien tersebut Positif Tuberkulosis atau Pasien Mengalami Tuberkulosis Paru. Dampak dari riset ini masyarakat dapat mendiagnosis secara mandiri sehingga dapat mengetahui gejala awal dari $t u$ berculosis.
\end{abstract}

Kata kunci: Laplace Correction, Nä̈ve Bayes, Program Aplikasi, Sistem Pakar, Tuberkulosis Paru 


\section{ABSTRACT}

Tuberculosis or tuberculosis (TBC) is a dangerous infectious disease caused by germs from the Mycobacterium Tuberculosis group. Most tuberculosis germs attack the lungs and other organs. According to WHO, Indonesia is one of the countries with a high burden of tuberculosis with the latest number of tuberculosis cases in Indonesia reaching 420,994 cases in 2017, this is influenced by the lack of public knowledge about tuberculosis, and reluctance to check the initial symptoms suffered by a doctor.

From these problems, it is necessary to build an expert system based on software that aims to assist and facilitate the community in diagnosing the early symptoms of tuberculosis before consulting further health workers. Diagnosis of disease using an expert system requires an algorithmic method in its completion. In this research, the method used to build an expert system software for pulmonary tuberculosis diagnosis uses a waterfall, while the classification process to determine the diagnosis uses Nä̈ve Bayes algorithms with Laplace Correction. The purpose of this research is to diagnose the symptoms experienced by patients and to be able to conclude like an expert or doctor when diagnosing patients and to provide knowledge of what disorders the patient is experiencing.

Related to the results of this research is in the form of an expert system application for pulmonary tuberculosis diagnosis based on desktop, and testing of tuberculosis diagnosis software has been carried out, by comparing the diagnostic results for positive tuberculosis class and tuberculosis negative class with Laplace Correction. with a value of 0.000129803, compared to the value of the Negative Tuberculosis class with a value of 0.0000000018. So it can be stated that the patient is POSITIVE TUBERCULOSIS or the patient has pulmonary tuberculosis. The impact of this research is that people can self-diagnose so they can find out the early symptoms of tuberculosis.

Keywords: Laplace Correction, Nä̈ve Bayes, Application Program, Expert System, Pulmonary Tuberculosis.

\section{PENDAHULUAN}

Sebagian besar kuman tuberkulosis menyerang organ paru-paru, namun tidak menutup kemungkinan juga dapat mengenai organ-organ tubuh lainnya. Penyakit ini memerlukan penanganan yang intensif, setidaknya diperlukan pengobatan minimal 9 sampai 12 bulan waktu yang harus ditempuh oleh pasien secara rutin dan terus menerus.(Azizah, 2020) Tuberkulosis menjadi salah satu penyakit yang menyebabkan kematian paling tinggi, dibandingkan dengan penyakit lainnya. Penyakit tuberculosis dapat menular dengan sangat mudah melalui cairan saluran pernafasan yang keluar ke udara lewat batuk atau bersin oleh seorang penderita tuberkulosis positif yang akan dihirup oleh orang-orang disekitarnya. (Kusuma, 2019).

Berdasarkan pada survei prevalensi tuberkulosis dari Kemenkes, diperoleh prevalensi pada laki-laki 3 kali lebih tinggi dibanding perempuan. Begitu juga yang terjadi 
pada negara-negara lain. Penyebabnya karena laki-laki berkemungkinan lebih terpapar pada faktor risiko tuberkulosis, misalnya merokok dan ketidakpatuhan dalam minum obat (Silalahi \& Fransiska, 2019). Survei ini menemukan bahwa dari seluruh partisipan laki-laki diketahui sebanyak 68,5\% merokok dan diperoleh data 3,7\% partisipan perempuan yang merokok dari keseluruhan partisipan perempuan. (Kemenkes RI, 2018)

Sulitnya dalam penegakan diagnosis karena kemiripan gejala yang ditimbulkan dengan penyakit lain dan proses pengobatan penyakit ini (Riliani, 2020). Oleh karenanya Dokter dalam melakukan diagnosis terhadap penyakit ini melalui pemeriksaan fisik didaerah paru atau dada dan juga pada gejala yang dialami pasien, kemudian dilanjutkan pada pemeriksaan tambahan yaitu foto rontgen dada dan tes laboraturium(Nurmalasari, R dan Apriantoro, 2020).

Kemajuan teknologi sangat membantu untuk mendeteksi atau memprediksi sesuatu yang akan terjadi. Misalnya seperti sistem pakar yang diterapkan dalam berbagai macam bidang keilmuan komputer dan kedokteran (Gunawan, 2019), salahsatu contohnya sistem pakar untuk menentukan hasil diagnosis suatu penyakit yang diderita oleh pasien.

Diagnosis penyakit dengan menggunakan sistem pakar memerlukan sebuah metode algoritma dalam penyelesaiannya, seperti algoritma klasifikasi decision tree, Nä̈ve Bayes, dan Support Vector Machne (Chazar \& Widhiaputra, 2020a). (Mutiara, 2020) Metode-metode yang sering dijumpai dalam sistem pakar untuk diagnosis penyakit seperti Metode Nä̈ve Bayes, forward chainning(Rachman, 2019), dan certainty factor (CF)(Hadi \& Diana, 2019).

Beberapa penelitian terkait sistem pakar adalah Diagnosis penyakit diantaranya adalah Diagnosis penyakit menular pada ayam menggunakan algortima Nä̈ve Bayes, hasil riset tersebut menunjukan data akurasi hasil pengolahan data sebesar 90\%(Windarto \& Marfuah, 2020), selanjutnya riset mengklasifikasikan penyakit Stroke dengan metode Nä̈ve Bayes, hasil riset menunjukan akurasi algoritma dalam efektifitas pengolahan data pada penyakit stroke sebesar 81,25\%, (Lishania, Goejantoro, \& Nasution, 2019), riset yang terkait selanjutnya riset klasifikasi prediksi penyakit tuberculosis dengan algoritma Nä̈ve Bayes, hasil riset tersebut menyimpulkan Nä̈ve Bayes memiliki akurasi pengolahan data tuberculosis sebesar 91\% sehingga dapat dikategorikan sangat baik. (Mutiara, 2020). Tetapi dari hasil paparan riset terkait yang telah di- 
paparkan, ditemukan kekurangan yaitu pembahasan masih dalam lingkup data dan belum di implementasikan kedalam perangkat lunak. Maka perlu adanya pengembangan riset lebih lanjut.

Berdasarkan hasil studi literatur dipilihlah metode Nä̈ve Bayes dengan laplace correction. Penggunaan metode Nä̈ve Bayes untuk algoritma sistem pakar diagnosis tuberkulosis paru, sedangkan metode pengembangan perangakt lunak yang akan digunakan pada riset ini adalah metode waterfall(Chazar \& Widhiaputra, 2020b). Tujuan dari riset ini adalah untuk mendiagnosis gejala-gejala yang dialami pasien dan dapat menyimpulkan layaknya seorang pakar atau dokter saat mendiagnosis pasiennya serta memberikan pengetahuan gangguan apa yang diderita oleh pasien. Sedangkan manfaat riset ini adalah dapat memudahkan masyarakat dalam mengetahui gejala tuberculosis sehingga dapat mengantisipasi secara cepat.

\section{METODE PENELITIAN}

\subsection{Sistem Pakar}

Sistem pakar atau Expert System biasa dipanggil juga sebagai Knowledge Based System adalah suatu aplikasi atau program komputer yang ditujukan dalam membantu mengambil keputusan(Suryana, Fauziah, \& Sari, 2020) atau pemecahan masalah pada bidang yang spesifik (Salman \& Abu-Naser, 2020). Dengan adanya sistem pakar seorang yang bukan pakar atau ahli akan bisa menjawab pertanyaan, menyelesaikan permasalahan dan juga mengambil keputusan yang biasanya dilakukan oleh seorang ahli atau pakar (MZ, Wijaya, \& Bimantoro, 2020).

\subsection{Metode Nä̈ve Bayes}

Nä̈ve Bayes adalah suatu metode klasifikasi yang berasal dari Teorema Bayes. Metode pengklasifikasian menggunakan metode probabilitas yang diperkenalkan oleh seorang ilmuwan Inggris yaitu Thomas Bayes. Pada data mining biasanya Nä̈ve Bayes digunakan untuk mengklasifikasikan kelas data training dan testing dari data yang tidak terstruktr sehingga menghasilkan pola pengetahuan yang dapat dimanfaatkan untuk analisis sentiment, klasifikasi, optimasi, dan prediksi (Priyono et al., 2017) Langkahlangkah atau tahapan dari proses Nä̈ve Bayes adalah sebagai berikut:(Untoro, Praseptiawan, \& Widianingsih, 2020) (1) Menghitung jumlah kelas per label, (2) 
Menghitung jumlah kasus per kelas, (3) Kalikan semua variable per kelas (4) Bandingkan hasil per kelas.

Formula yang digunakan dalam teorema bayes adalah sebagai berikut (Deshpande, 2015):

$P(C \mid X)=\frac{P(X \mid C) P(C)}{P(X)}$

Keterangan:

$X \quad$ : Data dengan class yang belum diketahui.

C : Hipotesis data E merupakan suatu class spesifik.

$P(C \mid X)$ : Peluang hipotesis berdasar kondisi (posterior probability).

$P(C) \quad$ : Peluang hipotesis (prior probability).

$P(X \mid C)$ : Peluang berdasarkan kondisi pada hipotesis.

$P(X) \quad$ : Probabilitas C.

Implementasi Algoritma dapat dilihat pada script berikut:

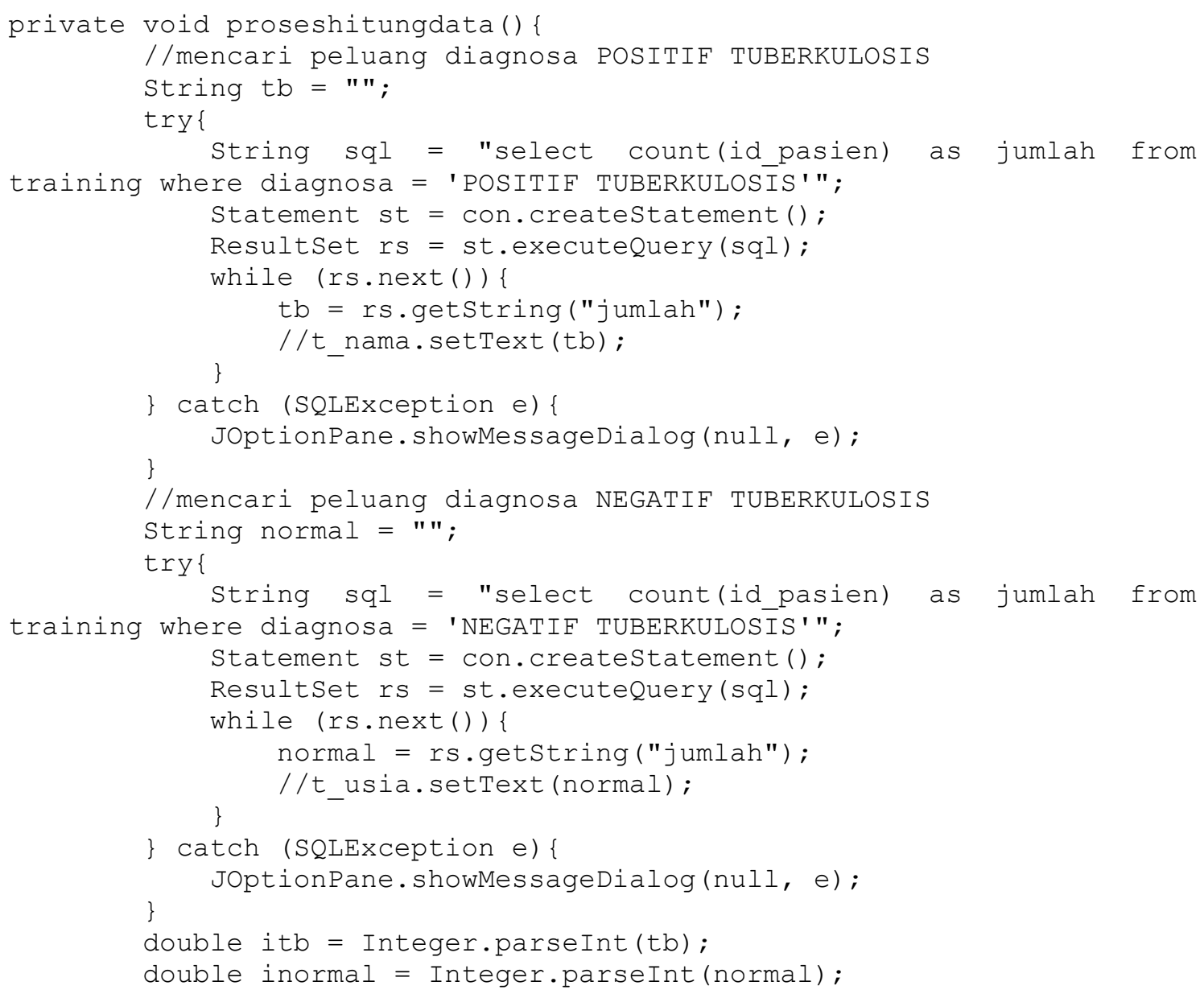




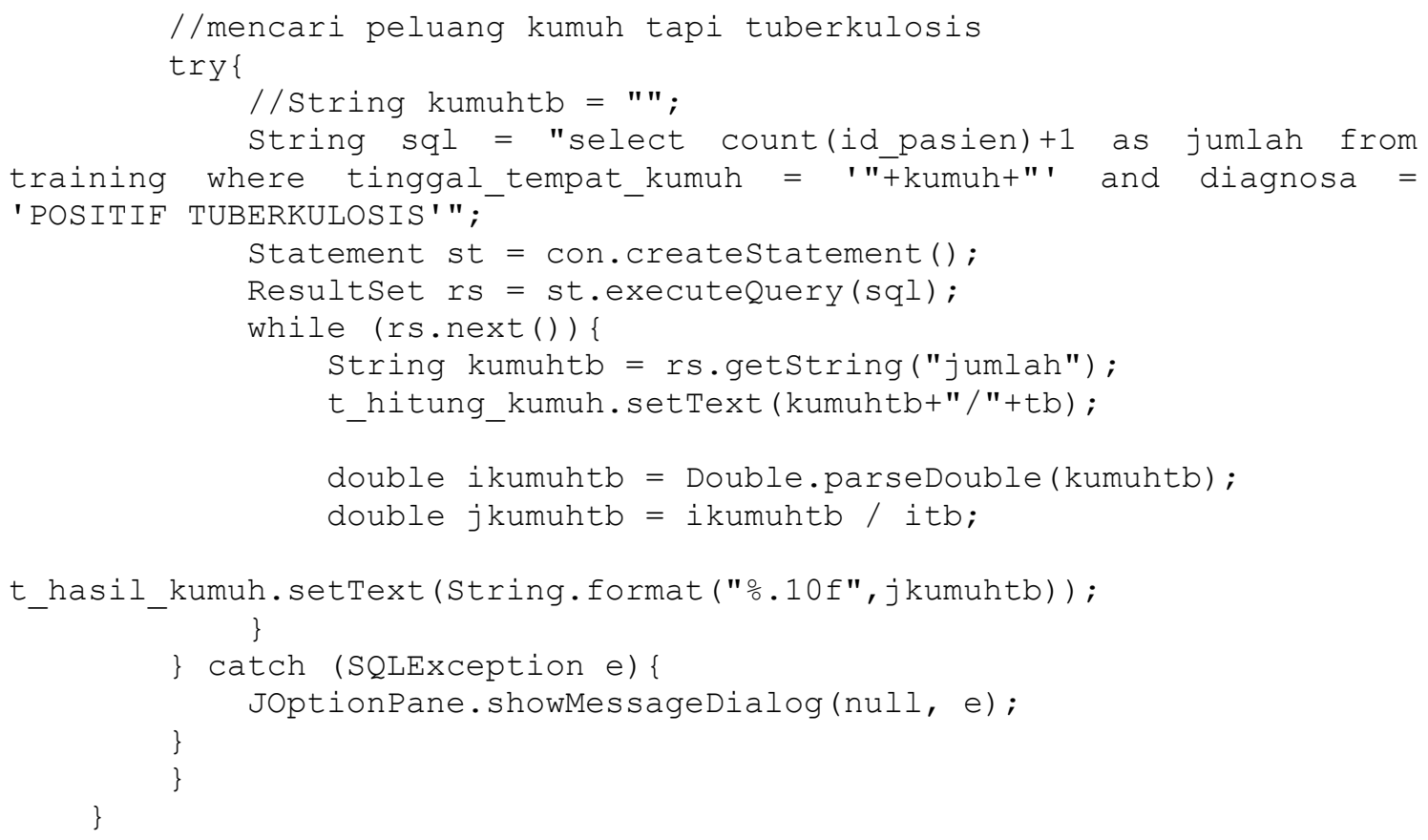

Untuk script algoritma lebih lengkap dapat di unduh pada link berikut: https://github.com/iqbaldzi13/Algoritma-Naive-Bayes-berbasis-Java

\subsection{Metode Laplace Correction}

Proses prediksi untuk menghindari probabailitas 0 (nol) yang dapat menyebabkan Naïve Bayes tidak dapat mengklasifikasi sebuah data inputan dengan baik. Maka digunakan teknik metode Laplace Correction (Imanidanantoyo, Ananta, \& Kirana, 2020). Suatu teknik yang menambahkan nilai 1 pada setiap kombinasi atribut. Dengan persamaan sebagai berikut(Indrajaya, 2018):

$P(X k \mid C)=\frac{P(X k \mid C)+1}{P(C)+|V|}$

Keterangan :

$P(X k \mid C) \quad$ : Probabilitas tiap atribut $X k$

$P(C) \quad$ : Total probabilitas dalam $X k$

$|\mathrm{V}| \quad$ : Jumlah kemungkinan nilai $X k$

\subsection{Model Pengembangan Perangkat Lunak Waterfall}

Model pengembangan perangkat lunak Waterfall diterapkan untuk membangun perangkat lunak secara terstruktur yang berskala besar dengan jangka waktu pengerjaan 
yang cukup lama. (Thummadi \& Lyytinen, 2020) Tahapan metode waterfall dimulai dari tahapan pertama yaitu Analisis, lalu dilanjutkan pada tahapan kedua Desain, tahapan ketiga Impelentasi, dan terakhir tahapan ke empat yaitu Pemeliharaan. Jika tahapan pertama belum selesai. Maka tidak dapat melanjutkan tahapan yang kedua dan seterusnya. (Iskandar, 2018). Dalam pembuatannya, program aplikasi berbasis desktop(Chazar \& Widhiaputra, 2020b) ini penulis melalui beberapa tahapan dalam penyelesaiannya sebagai berikut: (1) Membuat rancangan dasar dari program aplikasi Sistem Pakar Diagnosis penyakit Tuberkulosis Paru yang akan dibuat. Pada tahapan ini penulis melakukan riset terhadap program aplikasi terdahulu yang pernah ada sebelumnya guna dijadikan sebagai refrensi dari program yang akan dibuat oleh penulis. (2) Membuat program aplikasi diagnosis tuberkulosis paru. Penerapan rancangan dan diimplementasikan pada program yang sedang dibuat serta menambahkan basis-basis pengetahuan dari seorang pakar ke dalam sistem. (3) Melakukan pengujian unit. Pengujian unit ini dilakukan menggunakan black box testing yang berfokus pada proses masukan dan keluaran dari aplikasi terhadap perangkat lunak Diagnosis penyakit tuberkulosis paru.

\subsection{Perancangan Dasar Program Sistem Pakar Diagnosis Penyakit Tuberkulosis Paru.}

Riset pada Perancangan Program Sistem Pakar Diagnosis penyakit tuberkulosis paru terdahulu sebagai referensi disajikan pada Gambar1.

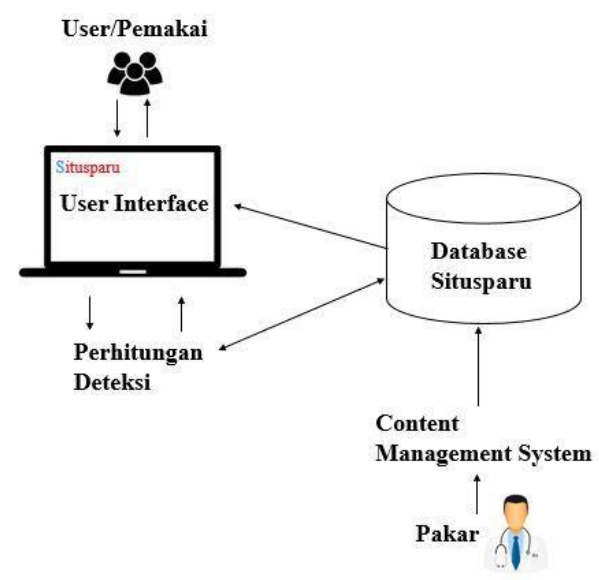

Sumber:(Surya \& Gunawan, 2018)

Gambar 1: Model Perancangan Sistem Pakar Diagnosis penyakit Tubekulosis Paru terdahulu 
Gambar 1 adalah Model perancangan Sistem Pakar Diagnosis penyakit Tuberkulosis paru yang telah dibuat pada riset terdahulu, hasil riset berupa program aplikasi berbasis website menggunakan metode certainty factor untuk algoritma sistem pakar Diagnosis penyakit tuberkulosis.(Surya \& Gunawan, 2018). Sebagai perbandingan dengan riset saat ini Perancangan Struktur menu dari aplikasi tersebut disajikan pada Gambar2.

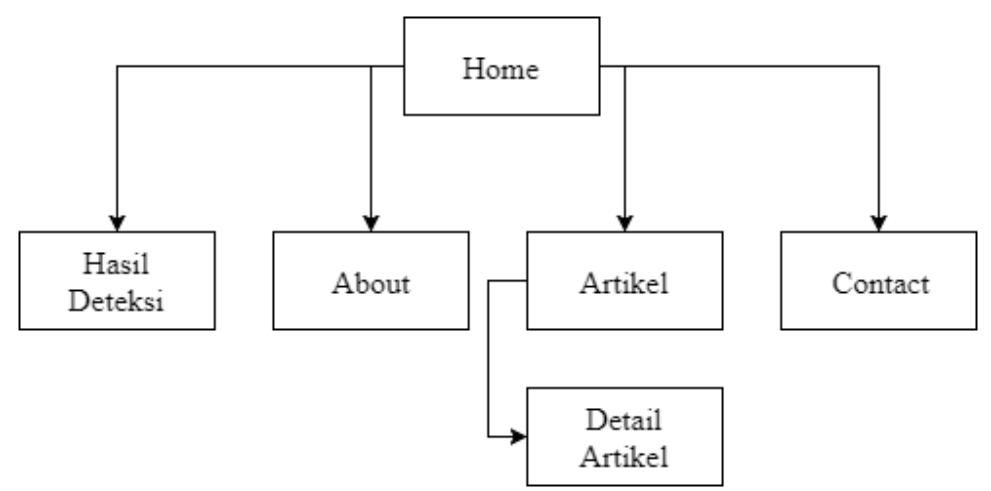

Sumber:(Surya \& Gunawan, 2018)

Gambar 2: Perancangan Struktur menu Aplikasi Sistem Pakar Diagnosis penyakit Tubekulosis Paru terdahulu

Gambar 2 adalah Perancangan Struktur menu Aplikasi Sistem Pakar deteksi penyakit Tubekulosis Paru terdahulu, yang nantinya akan dikembangkan dengan platform yang berbeda, yaitu aplikasi sistem pakar deteksi penyakit tuberculosis paru dengan metode Nä̈ve Bayes berbasis desktop, untuk perancangannya akan disajikan pada Gambar 3.

Gambar 3 adalah Flowchart Perancangan Struktur Aplikasi Sistem Pakar Diagnosis penyakit Tubekulosis Paru yang diusulkan. Untuk perancangan struktur menu dari flowchart tersebut akan disajikan pada Gambar 4. 


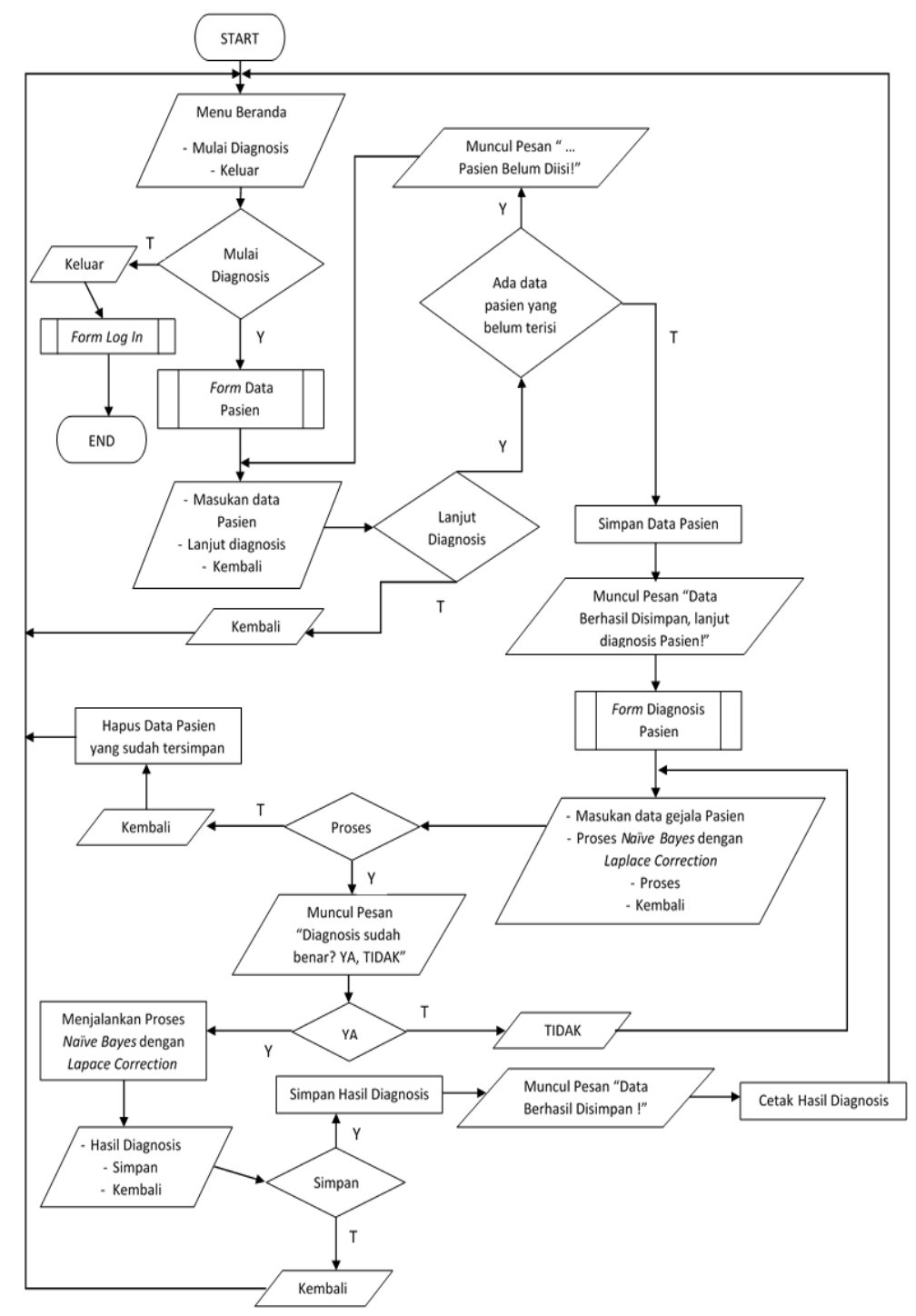

Gambar 3: Algoritma Flowchart Perancangan Struktur Aplikasi Sistem Pakar Diagnosis penyakit Tubekulosis Paru yang diusulkan. 


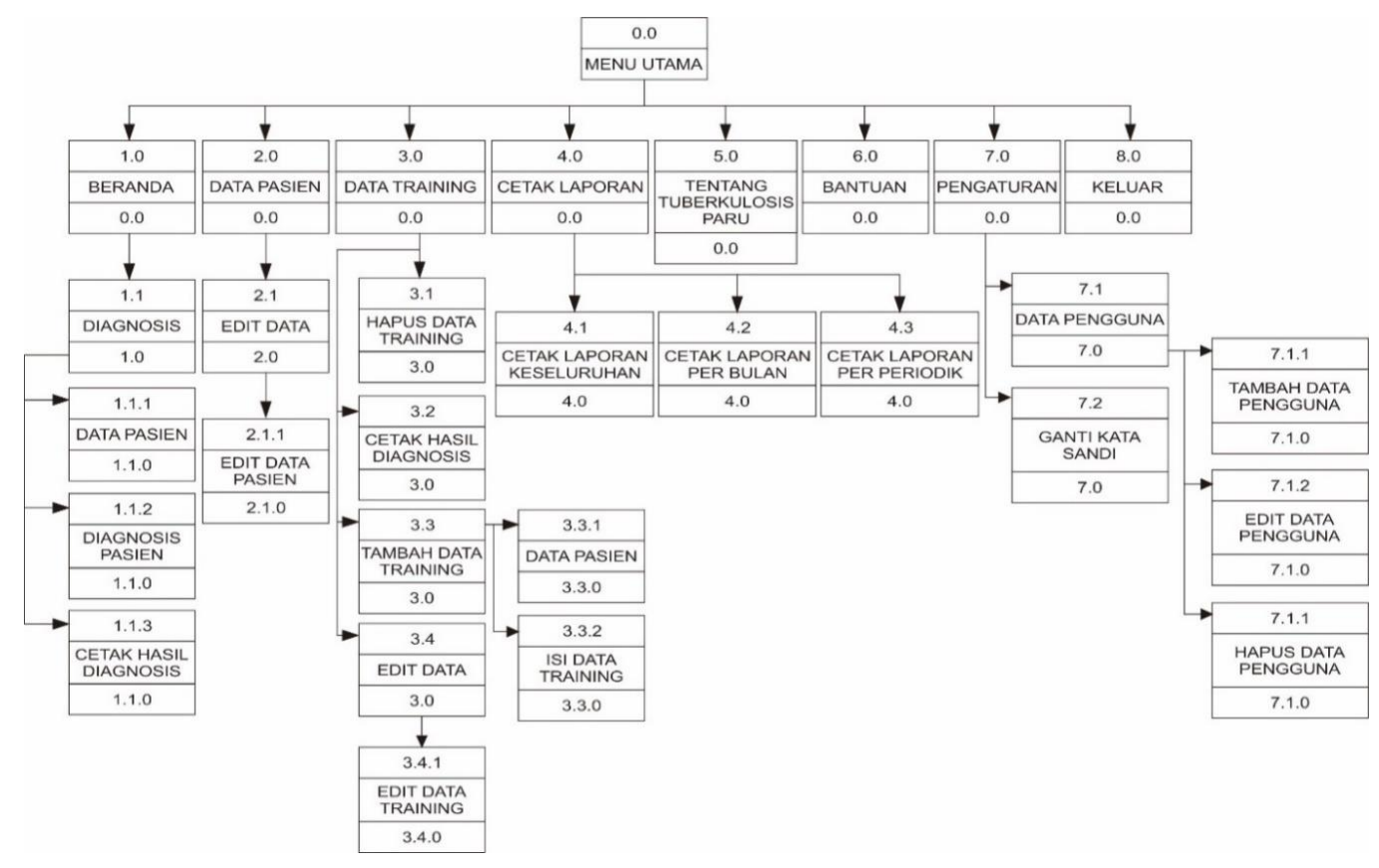

Gambar 4: Perancangan Struktur Menu Aplikasi Sistem Pakar Diagnosis penyakit Tubekulosis Paru yang diusulkan.

Gambar 4 adalah Perancangan Struktur Menu Aplikasi Sistem Pakar Diagnosis penyakit Tuberkulosis Paru yang diusulkan pada riset ini, terdapat perbedaan pada perancangan Struktur Menu Aplikasi Sistem Pakar Diagnosis penyakit Tuberkulosis Paru dengan riset terdahulu(Surya \& Gunawan, 2018). Pada riset ini struktur menu lebih kompleks yang bertujuan untuk melengkapi fitur yang ada pada plikasi sebelumnya, seperti Data Pasien, Data Training, dan Cetak Laporan Diagnosis. 


\subsection{Perancangan Basis Data}

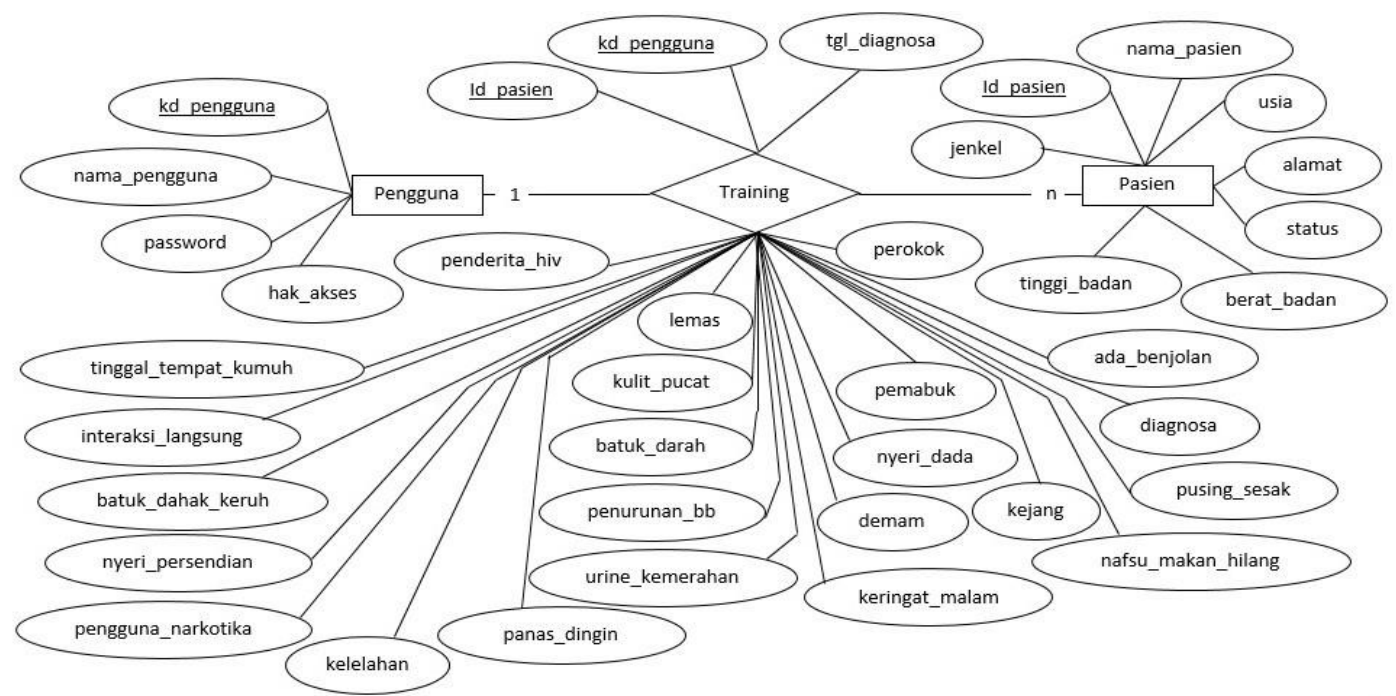

Gambar 5: Perancangan Entity Relational Diagram Basis data Aplikasi Sistem Pakar Diagnosis Penyakit tuberculosis yang disulkan

Gambar 5 adalah perancangan Entity Relational Diagram untuk Basis Data Sistem Pakar Diagnosis Aplikasi Sistem Pakar Diagnosis Penyakit tuberkulosis. Terdiri dari 3 entitas, yaitu Pengguna, Training, dan Pasien, yang memiliki kardinalitas satu pengguna(Admin) memiliki dapat mengdiagnosis banyak Pasien (1 to $\mathrm{N}$ ).

\subsection{Analisa Kebutuhan}

Berdasarkan hasil dari pengamatan proses mendiagnosis suatu penyakit oleh seorang pakar atau ahli dan apabila diimplementasikan pada suatu sistem pakar. Maka diperlukan suatu proses analisis kebutuhan agar hasil dan proses yang dilakukan sistem pakar akan sama dengan proses diagnosis yang dilakukan oleh seorang pakar atau ahli.(Dewi, 2020) Dalam aplikasi sistem pakar diagnosis tuberkulosis paru ini terdapat dua pengguna yang dapat saling berinteraksi dalam lingkungan sistem, yaitu: Admin, dan Super Admin. Skenario Kebutuhan Admin, Admin dapat Mengelola data pasien, Mengisi form data pasien, Mengisi form diagnosis pasien, Membuat hasil laporan diagnosis pasien, Skenario Kebutuhan Super Admin, Mengelola data pasien, Mengelola data training, Mengisi form data pasien, Mengisi form diagnosis pasien, Mengisi form data training, Mengelola laporan, Mengelola data pengguna. 


\section{HASIL DAN PEMBAHASAN}

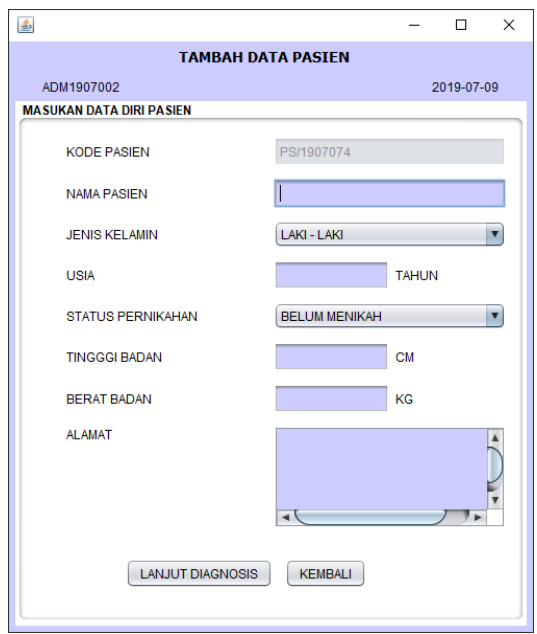

\section{Gambar 6:Form Data Pasien}

Gambar 6 adalah form untuk input data pasien, sebelum dilakukan diagnosis yan terdiri dari atribut kode pasien, nama pasien, jenis kelamin, usia, status pernikahan, tinggi badan, berat badan, dan alamat.

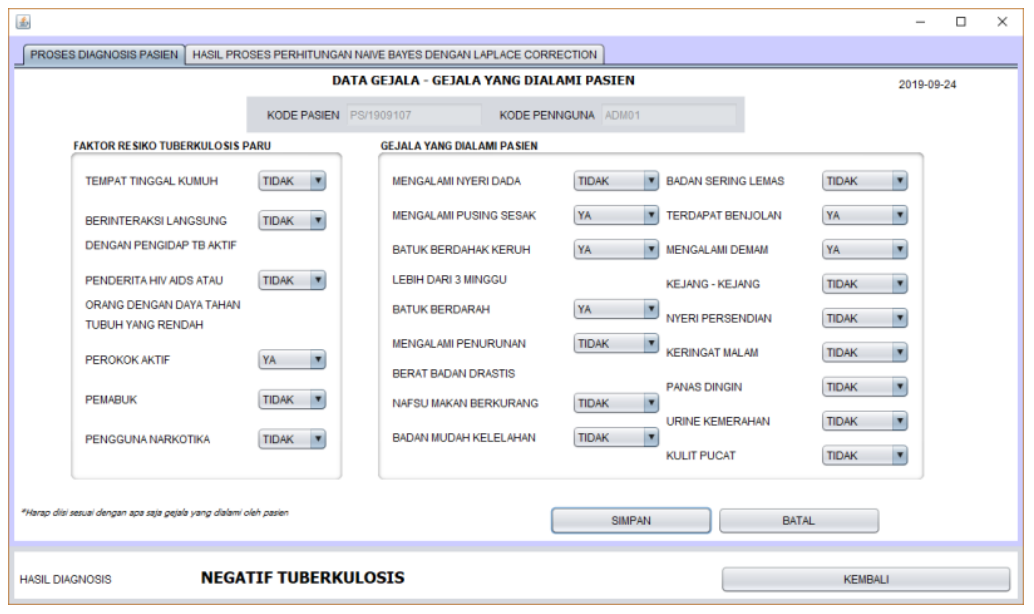

Gambar 7: Form Diagnosis Pasien

Gambar 7 adalah tampilan interface formulir yang digunakan untuk mendeteksi gejalagejala yang dialami oleh pasien. Selanjutnya Perangkat lunak akan merekam hasil screening pasien dan menyimpannya kedalam basis data.dan akan di proses dengan algoritma Nä̈ve Bayes dengan laplace correction yang disajikan pada gambar 8 . 


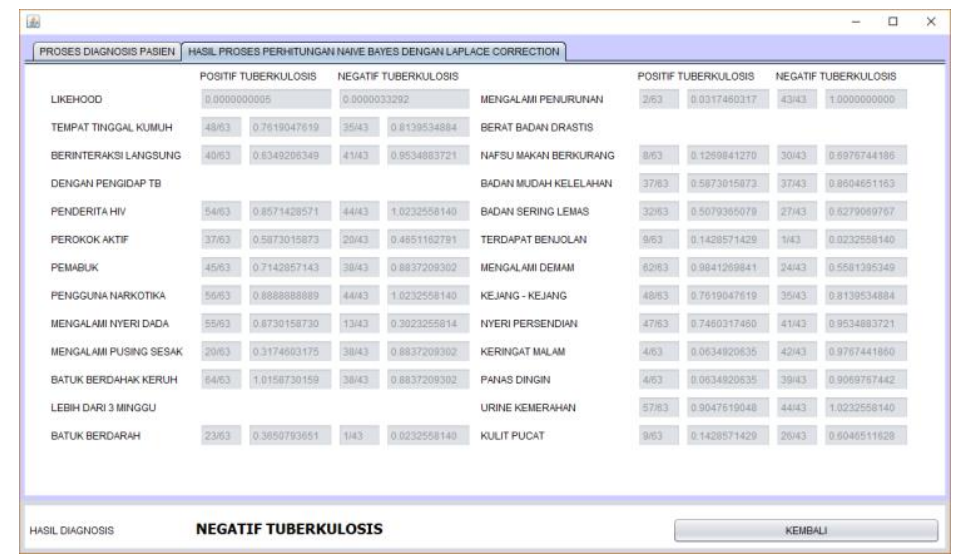

Gambar 8. Sub-form Proses Nä̈ve Bayes dengan Laplace Correction

Gambar 8 adalah tampilan user interface proses pengolahan data screening yang di input oleh pasien dengan menggunakan algoritma Nä̈ve Bayes dengan Laplace Correction yang nantinya akan menghasilkan pengetahuan berupa lembar hasil diagnosis pasien yang disajikan pada Gambar 9.

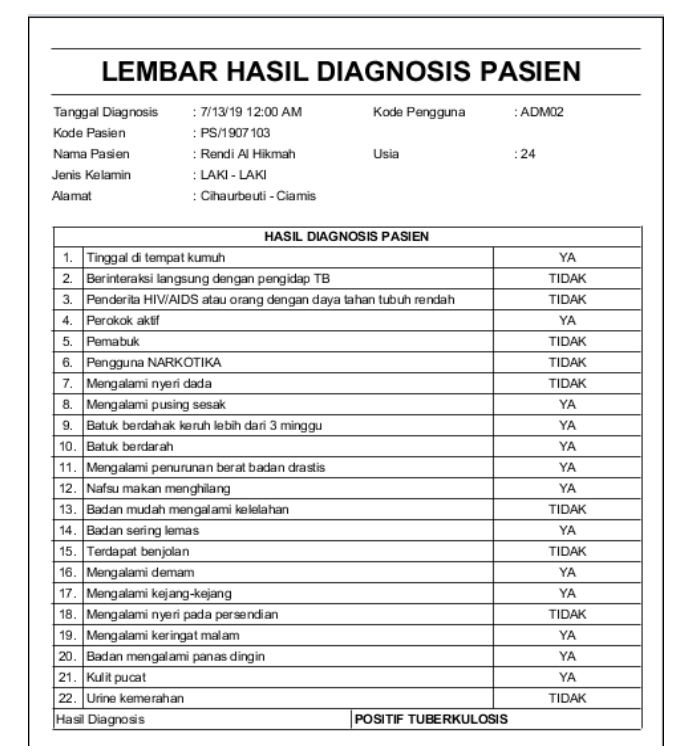

Gambar 9. Lembar Hasil Diagnosis Pasien

Gambar 9 adalah lembar hasil diagnosis pasien hasil dari pengolahan data algoritma Nä̈ve Bayes yang nantinya menjadi bahan referensi untuk dilakukan tindakan selanjutnya. Setelah aplikasi sistem pakar diagnosis penyakit tuberculosis paru selesai dibuat, selanjutnya dilakukan pengujian unit yang dilakukan menggunakan metode black box testing yang berfokus pada proses masukan dan keluaran dari aplikasi terhadap Aplikasi Diagnosis penyakit tuberkulosis paru. Hasil pengujian disajikan pada Tabel 1. 
Tabel 1. Hasil pengujian Aplikasi Sistem Pakar Diagnosis penyakit tuberkulosis paru dengan metode Black Box

\begin{tabular}{|c|c|c|c|c|c|}
\hline No. & Skenario pengujian & Test case & Hasil yang diharapkan & $\begin{array}{l}\text { Hasil pen- } \\
\text { gujian }\end{array}$ & Kesimpulan \\
\hline 1. & $\begin{array}{l}\text { Seluruh combo box } \\
\text { pada panel Faktor } \\
\text { Resiko Tuberkulo- } \\
\text { sis Paru dan panel } \\
\text { Gejala Yang Di- } \\
\text { alami Pasien mem- } \\
\text { ilih "TIDAK" pada } \\
\text { sub-form Proses } \\
\text { Diagnosis Pasien } \\
\text { kemudian klik } \\
\text { PROSES }\end{array}$ & $\begin{array}{l}\text { Tempat tingal ku- } \\
\text { muh: TIDAK } \\
\text { Berinteraksi lang- } \\
\text { sung dengan pen- } \\
\text { gidap TB: TIDAK } \\
\text { Penderita HIV Aids } \\
\text { atau orang dengan } \\
\text { daya tahan tubuh } \\
\text { rendah: TIDAK } \\
\text { Perokok aktif: } \\
\text { TIDAK } \\
\text { Pemabuk: TIDAK } \\
\text { Pengguna narkotika: } \\
\text { TIDAK } \\
\text { Mengalami nyeri } \\
\text { dada: TIDAK } \\
\text { Mengalami pusing } \\
\text { sesak: TIDAK } \\
\text { Batuk berdahak } \\
\text { keruh selama lebih } \\
\text { dari } 3 \text { minggu: } \\
\text { TIDAK } \\
\text { Batuk berdarah: } \\
\text { TIDAK } \\
\text { Mengalami } \\
\text { penurunan berat ba- } \\
\text { dan drastis: TIDAK } \\
\text { Nafsu makan berku- } \\
\text { rang: TIDAK } \\
\text { Badan mudah kele- } \\
\text { lahan: TIDAK } \\
\text { Badan sering lemas: } \\
\text { TIDAK } \\
\text { Terdapat benjolan: } \\
\text { TIDAK } \\
\text { Mengalami demam: } \\
\text { TIDAK } \\
\text { Kejang-kejang: } \\
\text { TIDAK } \\
\text { Nyeri persendian: } \\
\text { TIDAK } \\
\text { Keringat malam: } \\
\text { TIDAK } \\
\text { Panas dingin: } \\
\text { TIDAK } \\
\text { Urine kemerahan: } \\
\text { TIDAK } \\
\text { Kulit pucat: TIDAK }\end{array}$ & $\begin{array}{l}\text { Sistem menerima } \\
\text { perintah pengguna dan } \\
\text { menampilkan "Diagno- } \\
\text { sis Sudah Benar? YA, } \\
\text { TIDAK" jika "YA" sis- } \\
\text { tem melakukan perhi- } \\
\text { tungan Nä̈ve Bayes } \\
\text { dengan laplace correc- } \\
\text { tion sesuai gejala yang } \\
\text { dimasukan selanjutnya } \\
\text { menampilkan hasil diag- } \\
\text { nosis dan hasil perhi- } \\
\text { tungan pada sub-form } \\
\text { Hasil Proses Perhitungan } \\
\text { Nä̈ve Bayes Dengan } \\
\text { Laplace Correction jika } \\
\text { "TIDAK" kembali pada } \\
\text { tampilan terakhir dari } \\
\text { sub-form Proses Diagno- } \\
\text { sis Pasien }\end{array}$ & $\begin{array}{c}\text { Sesuai hara- } \\
\text { pan }\end{array}$ & Valid \\
\hline
\end{tabular}




\begin{tabular}{|c|c|c|c|c|c|}
\hline 2. & $\begin{array}{l}\text { Seluruh combo box } \\
\text { pada panel Faktor } \\
\text { Resiko Tuberkulo- } \\
\text { sis Paru dan panel } \\
\text { Gejala Yang Di- } \\
\text { alami Pasien mem- } \\
\text { ilih "YA" pada } \\
\text { sub-form Proses } \\
\text { Diagnosis Pasien } \\
\text { kemudian klik } \\
\text { PROSES }\end{array}$ & $\begin{array}{l}\text { Tempat tingal ku- } \\
\text { muh: YA } \\
\text { Berinteraksi lang- } \\
\text { sung dengan pen- } \\
\text { gidap TB: YA } \\
\text { Penderita HIV Aids } \\
\text { atau orang dengan } \\
\text { daya tahan tubuh } \\
\text { rendah: YA } \\
\text { Perokok aktif: YA } \\
\text { Pemabuk: YA } \\
\text { Pengguna narkotika: } \\
\text { YA } \\
\text { Mengalami nyeri } \\
\text { dada: YA } \\
\text { Mengalami pusing } \\
\text { sesak: YA } \\
\text { Batuk berdahak } \\
\text { keruh selama lebih } \\
\text { dari } 3 \text { minggu: YA } \\
\text { Batuk berdarah: YA } \\
\text { Mengalami } \\
\text { penurunan berat ba- } \\
\text { dan drastis: YA } \\
\text { Nafsu makan berku- } \\
\text { rang: YA } \\
\text { Badan mudah kele- } \\
\text { lahan: YA } \\
\text { Badan sering lemas: } \\
\text { YA } \\
\text { Terdapat benjolan: } \\
\text { YA } \\
\text { Mengalami demam: } \\
\text { YA } \\
\text { Kejang-kejang: YA } \\
\text { Nyeri persendian: } \\
\text { YA } \\
\text { Keringat malam: YA } \\
\text { Panas dingin: YA } \\
\text { Urine kemerahan: } \\
\text { YA } \\
\text { Kulit pucat: YA }\end{array}$ & $\begin{array}{l}\text { Sistem menerima } \\
\text { perintah pengguna dan } \\
\text { menampilkan "Diagno- } \\
\text { sis Sudah Benar? YA, } \\
\text { TIDAK" jika "YA" sis- } \\
\text { tem melakukan perhi- } \\
\text { tungan Nä̈ve Bayes } \\
\text { dengan laplace correc- } \\
\text { tion sesuai gejala yang } \\
\text { dimasukan selanjutnya } \\
\text { menampilkan hasil diag- } \\
\text { nosis dan hasil perhi- } \\
\text { tungan pada sub-form } \\
\text { Hasil Proses Perhitungan } \\
\text { Nä̈ve Bayes Dengan } \\
\text { Laplace Correction jika } \\
\text { "TIDAK" kembali pada } \\
\text { tampilan terakhir dari } \\
\text { sub-form Proses Diagno- } \\
\text { sis Pasien }\end{array}$ & $\begin{array}{c}\text { Sesuai hara- } \\
\text { pan }\end{array}$ & Valid \\
\hline
\end{tabular}




\begin{tabular}{|c|c|c|c|c|c|}
\hline 3. & $\begin{array}{l}\text { Sebagian combo } \\
\text { box pada panel } \\
\text { Faktor Resiko Tu- } \\
\text { berkulosis Paru } \\
\text { dan panel Gejala } \\
\text { Yang Dialami } \\
\text { Pasien memilih } \\
\text { "YA" secara acak } \\
\text { dan sebagian lagi } \\
\text { memilih "TIDAK" } \\
\text { secara acak pada } \\
\text { sub-form Proses } \\
\text { Diagnosis Pasien } \\
\text { kemudian klik } \\
\text { PROSES }\end{array}$ & $\begin{array}{l}\text { Tempat tingal ku- } \\
\text { muh: YA } \\
\text { Berinteraksi lang- } \\
\text { sung dengan pen- } \\
\text { gidap TB: TIDAK } \\
\text { Penderita HIV Aids } \\
\text { atau orang dengan } \\
\text { daya tahan tubuh } \\
\text { rendah: TIDAK } \\
\text { Perokok aktif: YA } \\
\text { Pemabuk: TIDAK } \\
\text { Pengguna narkotika: } \\
\text { TIDAK } \\
\text { Mengalami nyeri } \\
\text { dada: YA } \\
\text { Mengalami pusing } \\
\text { sesak: YA } \\
\text { Batuk berdahak } \\
\text { keruh selama lebih } \\
\text { dari } 3 \text { minggu: YA } \\
\text { Batuk berdarah: } \\
\text { TIDAK } \\
\text { Mengalami } \\
\text { penurunan berat ba- } \\
\text { dan drastis: YA } \\
\text { Nafsu makan berku- } \\
\text { rang: YA } \\
\text { Badan mudah kele- } \\
\text { lahan: TIDAK } \\
\text { Badan sering lemas: } \\
\text { TIDAK } \\
\text { Terdapat benjolan: } \\
\text { TIDAK } \\
\text { Mengalami demam: } \\
\text { YA } \\
\text { Kejang-kejang: } \\
\text { TIDAK } \\
\text { Nyeri persendian: } \\
\text { YA } \\
\text { Keringat malam: YA } \\
\text { Panas dingin: YA } \\
\text { Urine kemerahan: } \\
\text { TIDAK } \\
\text { Kulit pucat: YA }\end{array}$ & $\begin{array}{l}\text { Sistem menerima } \\
\text { perintah pengguna dan } \\
\text { menampilkan "Diagno- } \\
\text { sis Sudah Benar? YA, } \\
\text { TIDAK" jika "YA" sis- } \\
\text { tem melakukan perhi- } \\
\text { tungan Nä̈ve Bayes } \\
\text { dengan laplace correc- } \\
\text { tion sesuai gejala yang } \\
\text { dimasukan selanjutnya } \\
\text { menampilkan hasil diag- } \\
\text { nosis dan hasil perhi- } \\
\text { tungan pada sub-form } \\
\text { Hasil Proses Perhitungan } \\
\text { Nä̈ve Bayes Dengan } \\
\text { Laplace Correction jika } \\
\text { "TIDAK" kembali pada } \\
\text { tampilan terakhir dari } \\
\text { sub-form Proses Diagno- } \\
\text { sis Pasien }\end{array}$ & $\begin{array}{c}\text { Sesuai hara- } \\
\text { pan }\end{array}$ & Valid \\
\hline
\end{tabular}

Tabel 1 merupakan hasil pengujian Aplikasi Sistem Pakar Diagnosis penyakit Tuberkulosis paru dengan metode Black Box. Hasil pengujian meyimpulkan fungsi dalam pengoperasian dari setiap fitur aplikasi sudah sesuai harapan.

Selanjutnya dilakukan uji hasil aplikasi, dalam implementasi dari perhitungan metode Nä̈ve Bayes dengan Lapalce Correction ini diperlukan variabel penentu dalam menentukan hasil diagnosis tuberkulosis paru yaitu dengan menggunakan gejala-gejala 
yang dialami pasien sebagai data uji dengan ketentuan variabel-variabel disajikan pada tabel2.

Tabel 2. Contoh Jenis-jenis Gejala penyakit Tuberkulosis Paru

\begin{tabular}{ccc}
\hline No & \multicolumn{1}{c}{ Jenis Gejala } & Keterangan \\
\hline 1. & Tinggal Pada Tempat Kumuh & YA \\
\cline { 3 - 3 } & & TIDAK \\
\hline 2. & Berinteraksi Langsung Dengan & YA \\
\cline { 2 - 3 } & Pengidap TB & TIDAK \\
\hline 3. & Penderita HIV & YA \\
\hline 4. & Perokok Aktif & TIDAK \\
\hline 5. & Pemabuk & YA \\
& & TIDAK \\
\hline 6. & Pengguna Narkotika & TIDAK \\
\cline { 2 - 2 } & & YIDAK \\
\hline
\end{tabular}

Tabel 2 adalah contoh dari Jenis - Jenis Gejala penyakit yang dimasukan kedalam perangkat lunak sistem pakar diagnosis tuberculosis paru.

Tabel 3. Hasil Diagnosis penyakit Tuberkulosis Paru

\begin{tabular}{cll}
\hline No. & \multicolumn{1}{c}{ Hasil Diagnosis } & \multicolumn{1}{c}{ Keterangan } \\
\hline 1. & POSITIF & Pasien mengalami Tuberku- \\
& TUBERKULOSIS & losis Paru \\
2. & NEGATIF & Pasien tidak mengalami \\
& TUBERKULOSIS & Tuberkulosis Paru \\
\hline
\end{tabular}

Tabel.3 adalah contoh dari hasil klasifikasi Diagnosis gejala penyakit tuberculosis paru.

Tabel 4. Data Uji diagnosis penyakit Tuberkulosis Paru

\begin{tabular}{lc}
\hline Tinggal Pada Tempat Kumuh & YA \\
\hline Berinteraksi Langsung Dengan Pengidap TB & TIDAK \\
\hline Penderita HIV & TIDAK \\
\hline Perokok Aktif & YA \\
\hline Pemabuk & TIDAK \\
\hline Pengguna Narkotika & TIDAK \\
\hline
\end{tabular}

Tabel 4 adalah contoh data uji diagnosis penyakit Tuberkulosis Paru. Untuk Memulai perhitungan dengan mengikuti langkah-langkah dari proses perhitungan Nä̈ve Bayes 
dengan Laplace Correction disajikan pada tabel4. Terdapat 2 label kelas yang digunakan yaitu "POSITIF TUBERKULOSIS" dan "NEGATIF TUBERKULOSIS" kemudian dilakukan penjumlahan pada setiap label kelas. Kelas dengan label "POSITIF TUBERKULOSIS" Jika diketahui berjumlah 62 dan kelas dengan label "NEGATIF TUBERKULOSIS" dan jika diketahui berjumlah 42 dengan demikian jumlah total kelas pada data training yang dimiliki berjumlah 104. Selanjutnya dilakukan perhitungan Laplace Correction pada jumlah klasifikasi positif tuberkulosis dari setiap jumlah kelas yang ada dibagi dengan jumlah total data yang disajikan pada Tabel 4 .

Tabel 5. Perhitungan Laplace Correction Kasus Positif Tuberkulosis

\begin{tabular}{cccc}
\hline Kelas POSITIF TUBERKUOLIS & Hasil & Kelas POSITIF TUBERKUOLIS & Hasil \\
\hline$=(62 / 104)$ & 0,596153846 & $=(42 / 104)$ & 0,403846154 \\
\hline
\end{tabular}

Tabel 5 Perhitungan Laplace Correction Kasus Positif Tuberkulosis, dari hasil perhitungan didapatkan nilai 0,403846154. Selanjutnya dilakukan perhitungan dari setiap kasus terhadap masing-masing kelas pada data training berdasarkan kasus dari data uji sebelumnya ditambah satu karena menggunakan metode Laplace Correction kemudian dibagi dengan jumlah kelas, yang disajikan pada tabel 6 .

Tabel 6. Perhitungan Laplace Correction Kasus Positif Tuberkulosis per kelas

\begin{tabular}{clcccc}
\hline NO. & $\begin{array}{c}\text { Data Uji diagnosis penyakit } \\
\text { Tuberkulosis Paru }\end{array}$ & $\begin{array}{c}\text { Ket- } \\
\text { erangan }\end{array}$ & $\begin{array}{c}\text { Laplace } \\
\text { Correction }\end{array}$ & $\begin{array}{c}\text { Hasil perhitungan } \\
\text { Laplace Correction }\end{array}$ & Kelas \\
\hline 1 & Tinggal Tempat Kumuh & YA & $(16+1) / 62$ & 0,274194 & POSITIF TUBERKULOSIS \\
\hline 2 & Tinggal Tempat Kumuh & YA & $(9+1) / 42$ & 0,238095 & NEGATIF TUBERKULOSIS \\
\hline 3 & $\begin{array}{l}\text { Berinteraksi Langsung Dengan } \\
\text { Pengidap TB }\end{array}$ & TIDAK & $(39+1) / 62$ & 0,645161 & POSITIF TUBERKULOSIS \\
\hline 4 & $\begin{array}{l}\text { Berinteraksi Langsung Dengan } \\
\text { Pengidap TB }\end{array}$ & TIDAK & $(40+1) / 42$ & 0,97619 & POSITIF TUBERKULOSIS \\
\hline 6 & Penderita HIV & TIDAK & $(52+1) / 62$ & 0,854839 & POSITIF TUBERKULOSIS \\
\hline 7 & Penderita HIV & TIDAK & $(42+1) / 42$ & 1,02381 & POSITIF TUBERKULOSIS \\
\hline 8 & Perokok Aktif & YA & $(35+1) / 62$ & 0,580645 & POSITIF TUBERKULOSIS \\
\hline 9 & Pemabuk & YA & $(18+1) / 42$ & 0,452381 & NEGATIF TUBERKULOSIS \\
\hline 10 & Pemabuk & TIDAK & $(43+1) / 62$ & 0,709677 & POSITIF TUBERKULOSIS \\
\hline 11 & Pengguna Narkotika & TIDAK & $(36+1) / 42$ & 0,880952 & NEGATIF TUBERKULOSIS \\
\hline
\end{tabular}




\begin{tabular}{|c|c|c|c|c|c|}
\hline 12 & Pengguna Narkotika & TIDAK & $(42+1) / 42$ & 1,02381 & NEGATIF TUBERKULOSIS \\
\hline 13 & Mengalami Nyeri Dada & TIDAK & $(53+1) / 62$ & 0,870968 & POSITIF TUBERKULOSIS \\
\hline 14 & Mengalami Nyeri Dada & TIDAK & $(12+1) / 42$ & 0,309524 & NEGATIF TUBERKULOSIS \\
\hline 15 & Mengalami Pusing Sesak & YA & $(19+1) / 62$ & 0,322580645 & POSITIF TUBERKULOSIS \\
\hline 16 & Mengalami Pusing Sesak & YA & $(36+1) / 42$ & 0,880952381 & NEGATIF TUBERKULOSIS \\
\hline 17 & Batuk Berdahak Keruh & YA & $(62+1) / 62$ & 1,016129032 & POSITIF TUBERKULOSIS \\
\hline 18 & Batuk Berdahak Keruh & YA & $(36+1) / 42$ & 0,880952381 & NEGATIF TUBERKULOSIS \\
\hline 19 & Batuk Berdarah & YA & $(22+1) / 62$ & 0,37096774 & POSITIF TUBERKULOSIS \\
\hline 20 & Batuk Berdarah & YA & $(0+1) / 42$ & 0,02380952 & NEGATIF TUBERKULOSIS \\
\hline 21 & $\begin{array}{l}\text { Kasus Penurunan Berat } \\
\text { Badan }\end{array}$ & YA & $(61+1) / 62$ & 1 & POSITIF TUBERKULOSIS \\
\hline 22 & Penurunan Berat Badan & YA & $(1+1) / 42$ & 0,047619 & NEGATIF TUBERKULOSIS \\
\hline 23 & Kulit Pucat & YA & $(54+1) / 62$ & 0,887097 & POSITIF TUBERKULOSIS \\
\hline 24 & Kulit Pucat & YA & $(18+1) / 42$ & 0,452381 & NEGATIF TUBERKULOSIS \\
\hline 25 & Badan Mudah Kelelahan & TIDAK & $(35+1) / 62$ & 0,5806452 & POSITIF TUBERKULOSIS \\
\hline 26 & Badan Mudah Kelelahan & TIDAK & $(35+1) / 42$ & 0,8571429 & NEGATIF TUBERKULOSIS \\
\hline 27 & Badan Sering Lemas & YA & $(32+1) / 62$ & 0,532258 & POSITIF TUBERKULOSIS \\
\hline 28 & Badan Sering Lemas & YA & $(16+1) / 42$ & 0,404762 & NEGATIF TUBERKULOSIS \\
\hline 29 & Kasus Terdapat Benjolan & TIDAK & $(54+1) / 62$ & 0,887097 & POSITIF TUBERKULOSIS \\
\hline 30 & Terdapat Benjolan & TIDAK & $(42+1) / 42$ & 1,02381 & NEGATIF TUBERKULOSIS \\
\hline 31 & Mengalami Demam & YA & $(60+1) / 62$ & 0,983871 & POSITIF TUBERKULOSIS \\
\hline 32 & Mengalami Demam & YA & $(23+1) / 42$ & 0,571429 & NEGATIF TUBERKULOSIS \\
\hline 33 & Mengalami Kejang & TIDAK & $(16+1) / 62$ & 0,274194 & POSITIF TUBERKULOSIS \\
\hline 34 & Mengalami Kejang & TIDAK & $(9+1) / 42$ & 0,238095 & NEGATIF TUBERKULOSIS \\
\hline 45 & Mengalami Nyeri Persendain & TIDAK & $(45+1) / 62$ & 0,74193548 & POSITIF TUBERKULOSIS \\
\hline 46 & Mengalami Nyeri Persendain & TIDAK & $(39+1) / 42$ & 0,95238095 & NEGATIF TUBERKULOSIS \\
\hline 47 & Mengalami Keringat Malam & YA & $(59+1) / 62$ & 0,967741935 & POSITIF TUBERKULOSIS \\
\hline 48 & Mengalami Keringat Malam & YA & $(2+1) / 42$ & 0,071428571 & NEGATIF TUBERKULOSIS \\
\hline 49 & Mengalami Panas Dingin & YA & $(59+1) / 62$ & 0,967741935 & POSITIF TUBERKULOSIS \\
\hline 50 & Mengalami Panas Dingin & YA & $(5+1) / 42$ & 0,142857143 & NEGATIF TUBERKULOSIS \\
\hline 51 & $\begin{array}{l}\text { Kasus Nafsu Makan } \\
\text { Menghilang }\end{array}$ & YA & $(55+1) / 62$ & 0,903226 & POSITIF TUBERKULOSIS \\
\hline 52 & $\begin{array}{l}\text { Mengalami Nafsu Makan } \\
\text { Menghilang }\end{array}$ & YA & $(14+1) / 42$ & 0,357143 & NEGATIF TUBERKULOSIS \\
\hline 53 & Mengalami Urine Kemerahan & YA & $(55+1) / 62$ & 0,903226 & POSITIF TUBERKULOSIS \\
\hline 54 & Mengalami Urine Kemerahan & TIDAK & $(42+1) / 42$ & 1,02381 & NEGATIF TUBERKULOSIS \\
\hline
\end{tabular}

Tabel 6 adalah Perhitungan Laplace Correction Kasus Positif Tuberkulosis per kelas, setelah hasil Laplace Correction diketahui, selanjutnya mengakalikan semua variabel per kelas, Berdasarkan kelas Positif Tuberkulosis 


$$
\begin{aligned}
& =0,596153846 * 0,274194 * 0,645161 * 0,854839 * 0,580645 * 0,709677 * 0,887097 * \\
& 0,870968 * 0,322580645 * 1,016129032 * 0,37096774 * 1 * 0,887097 * 0,5806452 * \\
& 0,532258 * 0,887097 * 0,983871 * 0,274194 * 0,74193548 * 0,967741935 * 0,967741935 * \\
& 0,903226 * 0,903226 \\
& =0.0001298030
\end{aligned}
$$

Berdasarkan kelas Negatif Tuberkulosis

$$
\begin{aligned}
& =0,403846154 * 0,238095 * 0,97619 * 1,02381 * 0,452381 * 0,880952 * 1,02381 * \\
& 0,309524 * 0,880952381 * 0,880952381 * 0,02380952 * 0,047619 * 0,452381 * 0,8571429 \\
& * 0,404762 * 1,02381 * 0,571429 * 0,238095 * 0,95238095 * 0,071428571 * 0,142857143 * \\
& 0,357143 * 1,02381 \\
& =0.0000000018
\end{aligned}
$$

Bandingkan hasil per kelas. Berdasarkan hasil perhitungan pada langkah tiga, dipatkan hasil yang disajikan pada tabel 6.

Tabel 7. Perhitungan Laplace Correction Kasus Positif Tuberkulosis per kelas

\begin{tabular}{cc}
\hline POSITIF TUBERKULOSIS & NEGATIF TUBERKULOSIS \\
\hline 0.0001298030 & 0.0000000018 \\
\hline
\end{tabular}

Tabel 6 adalah Perhitungan Laplace Correction Kasus Positif Tuberkulosis per kelas, Data menunjukan Kelas POSITIF TUBERKULOSIS lebih besar yaitu 0.0001298030, dibandingkan dengan nilai Kelas NEGATIF TUBERKULOSIS dengan nilai 0.0000000018. Maka dapat dinyatakan hasil dari proses diagnosis pasien yang telah dilakukan, bahwa pasien tersebut POSITIF TUBERKULOSIS atau Pasien Mengalami Tuberkulosis Paru.

\section{SIMPULAN}

Riset dengan judul Implementasi Sistem Pakar Dengan Algortima Nä̈ve Bayes dengan Laplace Correction Untuk Diagnosis Tuberkulosis Paru dapat dilakukan dan dapat dipergunakan oleh para tenaga medis guna mempermudah dan mempercepat proses pendiagnosisan tuberkulosis paru agar dapat memberikan tindakan cepat tanggap kepada pasien. Hasil pengujian Aplikasi Sistem Pakar Diagnosis penyakit Tuberkulosis paru dengan metode Black Box meyimpulkan fungsi dalam pengoperasian dari setiap fitur aplikasi sudah sesuai harapan. Sedangkan hasil pengujian proses dari Aplikasi Al- 
goritma sistem pakar Diagnosis penyakit tuberkulosis dengan membandingkan hasil Diagnosis kelas Positif tuberkulosis dan kelas negatif tuberculosis dengan metode Laplace Correction menyimpulkan hasil diagnosis menunjukan Kelas Positif Tuberkulosis lebih besar dengan nilai 0.000129803, dibandingkan dengan nilai kelas Negatif Tuberkulosis dengan nilai 0.0000000018. Maka dapat dinyatakan bahwa pasien tersebut POSITIF TUBERKULOSIS atau Pasien Mengalami Tuberkulosis Paru. Saran untuk riset dimasa mendatang aplikasi sistem pakar dapat di implementasikan kedalam bahasa pemrograman internet, sehingga dapat dijangkau oleh masyarakat yang lebih luas.

\section{DAFTAR PUSTAKA}

Azizah, I. (2020). Determinan Lama Waktu Kesembuhan pada Pengobatan Pasien Tuberkulosis Kategori I. HIGEIA (Journal of Public Health Research and ..., 4(Special 3), 574-583. $\quad$ Retrieved from https://journal.unnes.ac.id/sju/index.php/higeia/article/view/34565

Chazar, C., \& Widhiaputra, B. E. (2020a). Machine Learning Diagnosis Kanker Payudara Menggunakan Algoritma Support Vector Machine. INFORMASI (Jurnal Informatika Dan Sistem Informasi), 12(1), 67-78.

Chazar, C., \& Widhiaputra, B. E. (2020b). Perancangan Program Aplikasi Pemesanan Tiket Sepak Bola Berbasis Desktop Menggunakan Visual Studio 2010. INFORMASI (Jurnal Informatika Dan Sistem Informasi), 12(1), 67-78.

Deshpande, V. K. (2015). Predictive Analytics and Data Mining. Wyman Street, Waltham, MA 02451, USA: Elsevier Inc.

Dewi, L. P. K. (2020). Pemeriksaan Basil Tahan Asam Untuk Membantu Menegakkan Diagnosis Penyakit Tuberkulosis. International Journal of Applied Chemistry Research, 1(1), 16. https://doi.org/10.23887/ijacr.v1i1.28716

Gunawan, H. (2019). APLIKASI SISTEM PAKAR PENGOPERASIAN DAN TROUBLESHOOTING PADA MESIN HEIDELBERG GTO V 52. Informasi, $X(1)$, 44-77. Retrieved from http://informasi.stmik-im.ac.id/sistem-pendukungkeputusan-memilih-jurusan-di-perguruan-tinggi-menggunakan-metode-analyticalhierarchy-process-ahp/

Hadi, F., \& Diana, Y. (2019). Sistem Pakar Diagnosa Penyakit Limfoma dengan Metode Certainty Factor Dasril. SATIN - Sains Dan Teknologi Informasi, 5(2), 44-51. Retrieved from https://core.ac.uk/download/pdf/295386972.pdf

Imanidanantoyo, A. I., Ananta, A. Y., \& Kirana, A. P. (2020). Implementasi Naive Bayes Dan Pos Tagging Menggunakan Metode Hidden Markov Model Viterbi Pada Analisa Sentimen Terhadap Akun Twitter Presiden Joko Widodo Di Saat Pandemi COVID-19. Seminar Informatika Aplikatif Polinema, 235-241. 
Indrajaya, D. (2018). SISTEM PENDUKUNG KEPUTUSAN PERIZINAN SANTRI MENGGUNAKAN METODE NAÏVE BAYES CLASSIFIER DENGAN LAPLACE CORRECTION. 1-6.

Iskandar, I. D. (2018). Implementasi Algoritma Edit Distance Pada Pengembangan Aplikasi E-Learning Bsi.

Kemenkes RI. (2018). Infodatin Tuberkulosis. Kementerian Kesehatan RI, pp. 1-8. Retrieved from https://pusdatin.kemkes.go.id/resources/download/pusdatin/infodatin/infodatintuberkulosis-2018.pdf

Kusuma, S. A. K. (2019). Deteksi Dini Tuberkulosis Sebagai Upaya Pencegahan Penularan Penyakit Tuberkulosis Dan Pengolahan Herbal Antituberkulosis $\begin{array}{llll}\text { Berbasis } & \text { Riset. } & \text { Dharmakarya, } & 8(2),\end{array}$ https://doi.org/10.24198/dharmakarya.v8i2.19484

Lishania, I., Goejantoro, R., \& Nasution, Y. N. (2019). Perbandingan Klasifikasi Metode Naive Bayes dan Metode Decision Tree Algoritma (J48) pada Pasien Penderita Penyakit Stroke di RSUD Abdul Wahab Sjahranie Samarinda. Jurnal Eksponensial, 10(2), 135-142.

Mutiara, E.-. (2020). Algoritma Klasifikasi Naive Bayes Berbasis Particle Swarm Optimization Untuk Prediksi Penyakit Tuberculosis (Tb). Swabumi, 8(1), 46-58. https://doi.org/10.31294/swabumi.v8i1.7668

MZ, A. R., Wijaya, I. G. P. S., \& Bimantoro, F. (2020). Sistem Pakar Diagnosa Penyakit Kulit pada Manusia dengan Metode Dempster Shafer. Journal of Computer Science and Informatics Engineering (J-Cosine), 4(2), 129-138. https://doi.org/10.29303/jcosine.v4i2.285

Nurmalasari, R dan Apriantoro, N. H. (2020). Pemeriksaan Radiografi Thorax Dengan Kasus Tuberkulosis Paru. KOCENIN Serial Konferensi No.1, 1(1), 1-6. Retrieved from http://publikasi.kocenin.com/index.php/pakar/article/view/25/20

Priyono, F., Kanti, S., I, I. D., Amirulloh, I., P, E. S., \& Rosiyadi, D. (2017). Analisis Sentimen Media Sosial Opini Ujian Nasional Berbasis Komputer menggunakan Metoda Naive Bayes. 1(2), 38-45.

Rachman, R. (2019). Penerapan Sistem Pakar Untuk Diagnosa Autis Dengan Metode Forward Chaining. Jurnal Informatika, 6(2), 218-225. https://doi.org/10.31311/ji.v6i2.5522

Riliani, R. (2020). Neonatus Dari Ibu Tuberkulosis Aktif. Jurnal Ilmu Kesehatan Indonesia, 1(1), 1-4. https://doi.org/10.25077/jikesi.v1i1.14

Salman, F. M., \& Abu-Naser, S. S. (2020). Expert System for COVID-19 Diagnosis. International Journal of Academic Information Systems Research, 4(3), 1-13. Retrieved from www.ijeais.org/ijaisr 
Silalahi, N., \& Fransiska, S. (2019). Analisis Kebiasaan Merokok Terhadap Kejadian Tuberkulosis Paru Di Wilayah Kerja Puskesmas Patumbak. Jurnal Penelitian Kesmasy, 1(2), 83-90. https://doi.org/10.36656/jpksy.v1i2.172

Surya, R., \& Gunawan, D. (2018). Situsparu: Sistem Pakar Untuk Deteksi Penyakit Tuberkulosis Paru. Jurnal ULTIMATICS, 10(1), 41-47. https://doi.org/10.31937/ti.v10i1.781

Suryana, M. F., Fauziah, F., \& Sari, R. T. K. (2020). Implementasi Sistem Pakar Menggunakan Metode Certainty Factor Untuk Mendiagnosa Dini Corona Virus Desease (COVID-19). Jurnal Media Informatika Budidarma, 4(3), 559. https://doi.org/10.30865/mib.v4i3.2132

Thummadi, B. V., \& Lyytinen, K. (2020). How much method-in-use matters? A case study of agile and waterfall software projects and their design routine variation. Journal of the Association for Information Systems, 21(4), 864-900. https://doi.org/10.17705/1jais.00623

Untoro, M. C., Praseptiawan, M., \& Widianingsih, M. (2020). Evaluation of Decision Tree , K-NN , Naive Bayes and SVM with MWMOTE on UCI Dataset Evaluation of Decision Tree , K-NN , Naive Bayes and SVM with MWMOTE on UCI Dataset. https://doi.org/10.1088/1742-6596/1477/3/032005

Windarto, Y. E., \& Marfuah, M. (2020). Implementasi Naives Bayes-Certainty Factor untuk Diagnosa Penyakit Menular. Jurnal Sisfokom (Sistem Informasi Dan Komputer), 9(2), 208. https://doi.org/10.32736/sisfokom.v9i2.823 